\title{
Brand addiction: brand characteristics and psychological outcomes
}

\author{
Barbara Francioni and Ilaria Curina \\ Department of Communication Sciences, Humanities and International Studies, Università degli studi di Urbino Carlo Bo, Urbino, Italy \\ Sabrina M. Hegner \\ School of International Business, Bremen University of Applied Sciences, Bremen, Germany, and \\ Marco Cioppi \\ Department of Communication Sciences, Humanities and International Studies, Università degli studi di Urbino Carlo Bo, Urbino, Italy
}

\begin{abstract}
Purpose - This paper aims to empirically test the influence of brand characteristics on brand addiction, as well as the consumers' behaviors caused by this construct.

Design/methodology/approach - The paper adopts a Web-based self-completion survey by achieving a total of 529 completed surveys. Then, structural equation modeling has been employed by using SPSS AMOS.

Findings - Results highlighted how the brand characteristics of self-expressiveness, innovativeness and authenticity have a positive influence on brand addiction; brand addiction leads consumers to feel emotions of irritability and to adopt obsessive and compulsive behaviors toward the brand.

Research limitations/implications - Even if the choice of using a survey's sample composed of students attending an Italian University ensures good internal validity of research (owing to the homogeneous character), the results are not generalizable (except for this population group).

Practical implications - The study identified two different spheres of brand addiction (one connected to the brand's characteristics and the other to the consumers' psychological-behavioral outcomes), along with possible strategies firms could adopt to strengthen the possibilities to transform their customers into addicted ones and to avoid/reduce the negative consequences deriving from brand addiction.

Originality/value - The paper provides a response to the call for more studies into the brand addiction analysis by empirically testing possible antecedents and outcomes, thus enriching the existing quantitative research focused on this concept.
\end{abstract}

Keywords Brand addiction, brand characteristics, brand exclusiveness, Compulsive buying behavior, Irritability

Paper type Research paper

\section{Introduction}

In recent years, the analysis of the relationships between consumers and brands has achieved ever-more attention from scholars (Mrad et al., 2020).

Among these connections, brand addiction represents one of the most relevant ways in which consumers engage with brands (Reimann et al., 2012). Although some overlaps between brand addiction, brand love and brand loyalty can exist, research demonstrates that brand addiction is a distinct construct within consumer-brand relations (Cui et al., 2018).

Conceptually, research on brand addiction identifies both positive (Cui et al., 2018) and negative associations (Fournier and Alvarez, 2013) with this construct. In particular, Cui et al. (2018) mainly focused their attention on positive aspects of brand addiction by describing brand addicts as individuals who may experience a sense of gratification, happiness and pleasure from their brand addictive behaviors. From this positive perspective, brand addiction is viewed as a synthesis of some

The current issue and full text archive of this journal is available on Emerald Insight at: https://www.emerald.com/insight/0736-3761.htm

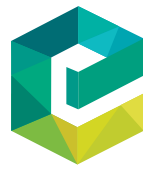

Journal of Consumer Marketing

38/2 (2021) 125-136

Emerald Publishing Limited [ISSN 0736-3761]

[DOI 10.1108/JCM-02-2020-3678] appetitive effects, such as satisfaction, gratification and peacefulness.

Conversely, Fournier and Alvarez (2013) investigated the dark features of brand addiction, thus defining it as an extremely close relation in which consumers can lose their own identities as they deepen their relationships with the specific brand toward which they feel a sense of addiction. In this way, the addictive connection becomes a very obsessive and destructive relation, leading consumers to adopt harmful behaviors, such as compulsive tendencies.

However, although different studies (Mrad et al., 2020; Mrad and Cui, 2020; Cui et al., 2018; Mrad and Cui, 2017) have recently focused their attention on brand addiction, this construct is still little investigated by the extant literature (Mrad et al., 2020), and a great deal of empirical research remains to

(C) Barbara Francioni and Ilaria Curina, Sabrina M. Hegner and Marco Cioppi. Published by Emerald Publishing Limited. This article is published under the Creative Commons Attribution (CC BY 4.0) licence. Anyone may reproduce, distribute, translate and create derivative works of this article (for both commercial and non-commercial purposes), subject to full attribution to the original publication and authors. The full terms of this licence maybe seen at http://creativecommons.org/licences/by/4.0/legalcode

Received 29 February 2020

Revised 2 September 2020

20 October 2020

Accepted 1 November 2020 
achieve (Cui et al., 2018). More specifically, recent literature underlines the relevance of investigating and empirically testing possible antecedents and outcomes of brand addiction (Cui et al., 2018; Mrad and Cui, 2017). Therefore, this paper attempts to address this deficiency.

In particular, the present study intends to enrich the extant research by:

- empirically investigating the influence of specific brand characteristics (i.e., brand hedonism, brand selfexpressiveness, brand innovativeness and brand authenticity) on brand addiction;

- analyzing and testing the relationships between brand addiction and the following consumers' psychological and behavioral outcomes, namely irritability, compulsive buying behaviors toward the addicted brand and brand exclusiveness.

By doing so, the work attempts to provide a response to the call for more studies testing the brand addiction antecedents and consequences, thus exploring the generalizability of the findings of the extant research focused on the brand addiction topic (Cui et al., 2018). Moreover, it appears to be the first research to empirically analyze the effect of specific brand characteristics and consumers' psychological and behavioral outcomes in the brand addiction context.

A summary of the research objectives is provided in Table 1 .

The remainder of the paper is structured as follows. Section 2 provides a framework focused on the brand addiction conceptualization along with the hypothesis development with relevant literature. Section 3 outlines the methodology, whereas Section 4 presents the results. Finally, Section 5 concludes the research by identifying the theoretical and managerial implications, as well as the limitations of the study and the potential directions for future research.

\section{Theoretical background and conceptual development}

\section{1 brand addiction conceptualization}

Brand addiction represents one of the most intense brandconsumer relationships (Cui et al., 2018). However, even if currently some studies (Mrad and Cui, 2020; Mrad et al., 2020; Cui et al., 2018; Mrad, 2018; Mrad and Cui, 2017) focused their attention on this construct, brand addiction within the literature is a very recent phenomenon and research studies remain rare (Mrad et al., 2020). Despite this scarcity of studies, some authors have still sought to conceptualize brand addiction systematically.

A first attempt has been provided by Fournier (1998) in her paper focused on consumer-brand relationships. In particular, the author conceptualized these relations along a continuum, ranging from non-intense feelings to passionate ones, which culminate in addictive obsession.

Subsequently, Fournier and Alvarez (2013) corroborated the negative characteristics of brand addiction by conceptualizing it as a very obsessive and destructive behavior, which could lead to the adoption of consumers' harmful actions, such as compulsive buying.

Conversely, Mrad and Cui (2017) mainly focused their attention on positive aspects of brand addiction. Notably, the authors developed a definition of brand addiction by also validating a brand addiction scale (BASCALE). Specifically, they defined brand addiction as:

[...] an individual consumer's psychological state (genus) that pertains to a self-brand relationship manifested in daily life and involving positive affectivity and gratification with a particular brand and constant urges for possessing the brand's products/services (Mrad and Cui, 2017, p. 1945).

In this respect, brand addiction is recognized as a newly emerged concept and a distinct phenomenon with respect to other categories such as brand attachment, brand love or brand loyalty.

By following the same research line, Mrad (2018) conducted a conceptual investigation to better analyze the nature of the brand addiction construct. More specifically, the author conceptualized brand addiction as a psychological state involving an emotional attachment to a specific brand, driven by a compulsive urge that generally brings to pleasure.

Based on the conceptual identification of the brand addiction salient features, the study of Cui et al. (2018) identified positive and negative implications of brand addiction with respect to the other types of consumer-brand relationships.

Subsequently, Mrad and Cui (2020) provided a significant contribution to the literature focused on addictive consumption and consumer-brand relationship. Notably, the authors demonstrated, on the one hand, that brand addiction

Table 1 Summary of research objectives

\begin{tabular}{|c|c|c|c|c|}
\hline & Extant Research & Studies & Literature gap & Research objectives \\
\hline Antecedents & $\begin{array}{l}\text { Analysis of specific brand } \\
\text { characteristics in the context } \\
\text { of consumer-brand } \\
\text { relationships different from } \\
\text { brand addiction }\end{array}$ & $\begin{array}{l}\text { Pappu and Quester (2016), } \\
\text { Schallehn et al. (2014); } \\
\text { Boisvert and Ashill (2011); } \\
\text { Bauer et al. (2007), Carroll and } \\
\text { Ahuvia (2006) }\end{array}$ & $\begin{array}{l}\text { The necessity of analyzing } \\
\text { these brand characteristics } \\
\text { within an ever stronger way of } \\
\text { brand-consumer engagement }\end{array}$ & $\begin{array}{l}\text { Analysis and test of the influence } \\
\text { of specific brand characteristics } \\
\text { (i.e. brand hedonism, brand } \\
\text { self-expressiveness, brand } \\
\text { innovativeness and brand } \\
\text { authenticity) in the brand addiction } \\
\text { context }\end{array}$ \\
\hline Outcomes & $\begin{array}{l}\text { Conceptual identification of } \\
\text { salient brand addiction } \\
\text { properties (also including } \\
\text { brand addiction } \\
\text { consequences) }\end{array}$ & $\begin{array}{l}\text { Cui et al. (2018), Mrad (2018); } \\
\text { Mrad and Cui (2017) }\end{array}$ & $\begin{array}{l}\text { The necessity of exploring and } \\
\text { empirically testing the } \\
\text { consequences of brand } \\
\text { addiction }\end{array}$ & $\begin{array}{l}\text { Analysis and test of the relationships } \\
\text { between brand addiction and three } \\
\text { consumer outcomes - namely } \\
\text { irritability, compulsive buying } \\
\text { behaviors toward the addicted brand } \\
\text { and brand exclusiveness }\end{array}$ \\
\hline
\end{tabular}


represents a distinctive phenomenon with respect to compulsive buying and, on the other, that brand addiction has a positive impact on debt avoidance, self-esteem and life happiness.

Finally, Mrad et al. (2020) identified the brand addiction main motivations and outcomes in the luxury and fast-fashion brands' context.

Overall, although in the past few years, different authors have attempted to define brand addiction, research on this construct is still in its infancy, with a myriad of brand addiction motivations and consequences to be empirically tested (Mrad et al., 2020; Cui et al., 2018; Mrad, 2018).

Therefore, the present paper aims to empirically test the influence of specific brand characteristics as possible antecedents of brand addiction; the relationship between brand addiction and possible psychological and behavioral outcomes.

Table 2 summarizes the extant literature on brand addiction.

\section{2 brand characteristics}

Consumers do not necessarily become addicted to all brands. In particular, individuals build long-term emotional relationships only with a few selected brands (Thomson et al., 2005). Moreover, people tend to engage in intense and passionate relationships only with brands having particular characteristics. Starting from this background, different authors have investigated the influence of specific brand features (brand hedonism, brand self-expressiveness, brand innovativeness and brand authenticity) in positive consumerbrand relationships, such as brand love (Albert and Merunka, 2013; Carroll and Ahuvia, 2006), brand passion (Bauer et al., 2007), brand loyalty (Pappu and Quester, 2016) and brand trust (Schallehn et al., 2014).

In the following sections, the influence of these brand characteristics will be analyzed within an even more intense way of brand-consumer engagement because, to the best of the authors' knowledge, no studies have focused, until now, their attention on the possible relationships between these brand characteristics and brand addiction.

\subsection{1 brand hedonism}

The primary benefit of hedonic brands is to procure, to consumers, feelings of fun, pleasure and enjoyment (Albert and Merunka, 2013).
Subsequently, Carroll and Ahuvia (2006) defined hedonism as the consumers' perception about the relative role of hedonic benefits (in opposition to utilitarian ones) provided by the brand. In particular, the authors tested and verified a positive influence of hedonic features on brand love. By continuing along the same line of research, Bauer et al. (2007) corroborated how the hedonic features of a brand can lead to passionate consumer-brand relationships, thus confirming the significant role of hedonic brand as an antecedent of brand passion.

Overall, starting from the assumption that the hedonic characteristics of a brand can lead consumers to nurture intense feelings toward brands (Kuikka and Laukkanen, 2012; Bauer et al., 2007; Carroll and Ahuvia, 2006), and that the most intense emotion between consumers and brands is brand addiction (Cui et al., 2018), it could be expected that the more a brand is perceived as hedonic by consumers, the more they will become addicted to it.

Based on these considerations, the first hypothesis is postulated:

H1. Brand hedonism has a positive effect on brand addiction.

\subsection{2 brand self-expressiveness}

Brand self-expressiveness represents a means through which consumers can express themselves (Aaker, 2009). In particular, Carroll and Ahuvia (2006, p. 82) defined brand selfexpressiveness as "the consumer's perception of the degree to which the specific brand enhances one's social self and/or reflects one's inner self." Moreover, the authors hypothesized a positive effect of brand self-expressiveness on brand love by confirming a positive relationship between the two constructs. Therefore, their results underlined how self-expressive brands tend to be more loved by consumers by provoking more intense emotional responses.

Subsequently, further contributions analyzed the influence of brand self-expressiveness on the formation of strong customer-brand relationships by especially corroborating its role as an antecedent of brand love (Karjaluoto et al., 2016; Loureiro et al., 2012), brand passion (Swimberghe et al., 2014; Bauer et al., 2007), brand tribalism (Ruane and Wallance, 2015), brand attachment (Lee and Workman, 2015), romantic brand jealousy (Sarkar and Sreejesh, 2014) and brand loyalty (Lee and Workman, 2015).

Table 2 Summary of existing studies on Brand addiction

\begin{tabular}{lll}
\hline Studies & Main focus & Study methodology \\
\hline Fournier (1998) & $\begin{array}{l}\text { Conceptualization of the consumer-brand relations along a continuum, } \\
\text { ranging from non-intense feelings to passionate ones, which can }\end{array}$ & Case study \\
culminate in addictive obsession & Survey \\
Fournier and Alvarez (2013) & $\begin{array}{l}\text { Identification of negative aspects of brand addiction } \\
\text { Definition of brand addiction and creation of a valid brand addiction } \\
\text { scale (BASCALE) }\end{array}$ & Focus-group; Survey \\
Mrad (2018) & Conceptual definition of brand addiction & Conceptual development procedure \\
Cui et al. (2018) & Conceptualization and definition of brand addiction & Focus-group; Interview \\
Mrad and Cui (2020) & Conceptual investigation focused on the comorbidity of compulsive & Survey; Structural equation model \\
Mrad et al. (2020) & buying and brand addiction & Interview \\
& Exploration of the main brand addiction motives and outcomes in two & \\
\hline
\end{tabular}


Overall, starting from this background and from the supposition that a self-expressive brand makes the connection between brands and customers more intense (Lee and Workman, 2015), and that brand addiction represents one of the most intense brand-consumer relationships (Cui et al., 2018), it could be hypothesized that the more a brand is perceived as self-expressive by consumers, the more they will become addicted to it.

In this respect, the second hypothesis can be formulated:

H2. brand self-expressiveness has a positive effect on brand addiction.

\subsection{3 brand innovativeness}

Brand innovativeness has recently been introduced in the perceived innovativeness literature (Shams et al., 2015). Notably, one of the first definitions of this construct has been provided by Quellet (2006), who conceptualized it as the consumers' perception about a brand's tendency to support new ideas, novelties, experimentations and creative processes.

Similarly, Eisingerich and Rubera (2010, p. 66) defined it as "the extent to which consumers perceive brands as being able to provide new and useful solutions to their needs." Moreover, the authors also found a positive relationship between brand innovativeness and brand commitment.

Subsequently, further definitions have been proposed by the more recent literature, such as the contributions of Barone and Jewell $(2014,2013)$, who described brand innovativeness as the degree to which individuals perceive a brand to be innovative, and that of Shams et al. (2015, p. 7), who conceptualized it as the “consumers' perception of a brand's track record of product innovations, degree of creativity and potential for continued innovative activity in the future in a given market." Through a regression analysis, the authors also identified a significant and positive influence of brand innovativeness on excitement toward the brand, customer satisfaction and purchase intention. A subsequent study of Shams et al. (2017) confirmed the positive relationship between brand innovativeness and customer purchase intention.

By defining brand innovativeness as the brand's capability to provide additional advantages over the customers' desired benefits, Srivastava et al. (2016) corroborated a positive relationship between brand innovativeness and brand trust.

With the aim of examining the relationship between consumers' perceptions of innovativeness and brand loyalty, Pappu and Quester (2016) identified how brand innovativeness influences perceived quality and brand loyalty. Furthermore, research also corroborated how innovativeness can positively influence consumers' cognitive and emotional satisfaction by also leading to more intense customer-brand involvements (Pappu and Quester, 2016).

Starting from these findings and from the assumption that brand addiction represents the most intense level of involvement between brands and customers (Cui et al., 2018), it could be expected that the more the consumers perceive a brand as innovative, the more they will become addicted to it. Hence, the third hypothesis can be formulated:

H3. Brand innovativeness has a positive effect on brand addiction.

\subsection{4 brand authenticity}

In the past years, the demand for reliable, honest and trustworthy customer-brand relations is significantly rising (Burnett and Hutton, 2007). In this context, brand authenticity can assume a key role in the creation of brand credibility and trust (Schallehn et al., 2014; Eggers et al., 2013). Notably, brand authenticity depends on the perceptions of its antecedents, namely, individuality, consistency and continuity (Schallehn et al., 2014). Individuality is described as the unique way in which brands fulfill their promises, consistency as the way in which brand promises are fulfilled at every single brand touchpoint, whereas continuity concerns the stability of the brand's core attributes over long periods. In this respect, consumers perceive continuity to be high if the present brand promises reflect the past brand behaviors.

Overall, the more the brand fulfills the individuality, consistency and continuity criteria, the more it is perceived by consumers as authentic. In turn, authenticity will allow establishing strong and intense relationships between consumers and brands (Schallehn et al., 2014). Given that brand addiction is one of the most intense ways in which consumers engage with brands (Cui et al., 2018), a positive relationship between brand authenticity and brand addiction could be hypothesized.

Therefore, the fourth hypothesis is structured as follows:

H4. Brand authenticity has a positive effect on brand addiction.

\subsection{Addictive brand outcomes}

Previous contributions (Martin et al., 2013; Sussman and Sussman, 2011) on addiction identified different potential behaviors of addicted consumers. In particular, Sussman and Sussman (2011) detected five addictive behavior elements, namely, feeling different, preoccupation with the behavior, temporary satisfaction, loss of control and negative consequences. Subsequently, Martin et al. (2013) identified four key dimensions of addictive consumption, namely, time spent and frequency of engaging in the behavior, degree of selfcontrol exerted by the individual, enjoyment of the behavior and degree of the negative consequences of harmful outcomes manifested in terms of psychological, behavioral, social or economic dimensions.

Starting from this framework, different studies, focused on brand addiction (Mrad and Cui, 2020; Cui et al., 2018; Mrad and Cui, 2017), analyzed the main outcomes resulting from this construct. In particular, Mrad and Cui (2017) hypothesized a positive influence of brand addiction on appearance esteem and life happiness. Moreover, in a subsequent study (2020), the authors tested and corroborated a positive relationship between brand addiction and debt avoidance, self-esteem and life happiness.

Finally, Mrad et al. (2020) investigated the main outcomes of brand addiction in the luxury and fast-fashion context by identifying:

- interpersonal relationships and financial issues as common themes for addiction to luxury and fast-fashion brands; and

- selectivity of style and motivation to work harder as addiction's outcomes to particular luxury brands. 
Against this background, the current study aims to empirically analyze further brand addiction consequences identified by previous contributions (Mrad, 2018; Cui et al., 2018), which have not yet been tested by the existing literature (i.e. irritability, compulsive buying behaviors toward the brand and brand exclusiveness)

\subsubsection{Irritability}

Overall, the irritability concept has been mainly investigated by psychological literature. In particular, Born and Steiner (1999) conceptualized it as a temporary psychological and emotional state which is characterized by impatience, intolerance and poorly controlled anger. More recently, Dickstein and Leibenluft (2012) defined it as an overreaction to negative emotional stimuli, such as frustration resulting from the incapacity to achieve a specific objective.

Focusing on brand addiction, only a few studies have analyzed the irritability construct by identifying it as a possible behavior manifested by addicted consumers.

In particular, Cui et al. (2018) and Mrad (2018) conceptualized it as a psychological state of anxiety that consumers may feel when they are unable to engage in activities connected to their addictive brand, a product of their favorite brand, that they are used to buy, becomes out of production, they are not able to buy their addictive brand. Overall, this means that irritability arises from the urgency to possess the favorite brand.

Starting from these previous findings, the fifth hypothesis aims to empirically test the relationship between brand addiction and irritability by postulating that the more the customers are addicted to a brand, the more they develop feelings of irritability (deriving from specific situations related to the brand).

Therefore, the fifth hypothesis is structured as follows:

H5. Brand addiction has a positive effect on irritability.

\subsubsection{Compulsive buying behaviors (toward the brand)}

Compulsive buying behavior represents one of the most analyzed customers' addictive attitudes by marketing literature (Park and Burns, 2005; Shoham and Makovec Brenčič, 2003). In particular, Edwards (1993) defined it as an excessive form of consumer shopping and spending in which consumers present an uncontrollable and compulsive urge to shop and spend.

By focusing on the brand addiction literature, Cui et al. (2018) detected how brand addicts manifest uncontrollable and compulsive urges related to the irresistible desire to get the addictive brand. In this respect, when consumers are obsessed with one brand, they feel obliged to buy it.

Moreover, the connection between brand addiction and compulsive behavior has also been studied in previous contributions, such as that of Fournier (1998). The author highlighted how intense relationships between brands and customers lead to addiction and compulsive buying and consumption behaviors. More recently, Reimann et al. (2012) found out how close consumer-brand relationships may lead to brand addiction, which is, in turn, associated with the activation of an individual's brain area denominated the insula. Notably, this specific brain area is responsible for addictive and compulsive behaviors.
Therefore, it could be hypothesized that the more the customers are addicted to a brand, the more they manifest compulsive buying behaviors toward it.

In this respect, the following hypothesis is postulated:

H6. Brand addiction has a positive effect on compulsive buying behaviors (toward the brand).

\subsection{3 brand exclusiveness}

Literature identified another potential addictive attitude, namely, brand exclusiveness (Cui et al., 2018). In particular, the authors defined it as:

[...] single mindedness and often unfair prejudice in favor of the brand, disregarding all other brands, focusing only on the addictive brands and seeing no other brands as better, regardless of price differences (Cui et al., 2018, p. 123).

Moreover, they underlined how brand addicts also manifest their addiction by limiting their consideration sets to their favorite brands, thus omitting any other alternative ones.

In this way, addicted consumers become single-minded by focusing all their attention only on their favorite brands, thus "seeing no other brands as better, regardless of price differences" (Cui et al., 2018, p. 120). In this respect, consumers are convinced that their favorite brand is the best one, to the point that they are unwilling to substitute the brands' products with other ones even if similar products are available at a lower price from different brands. Therefore, they are readily willing to pay double the price - with respect to competitive brands - to obtain their favored brand.

Moreover, brand exclusiveness can also lead addicted consumers to feel emotions of anger toward anyone talking badly about their favorite brand and anxiety related to any change regarding it. Indeed, brand exclusiveness is strictly related to a high level of brand sensitivity, meaning that brand addicts immediately recognize their favorite brand's intrinsic features. This tendency leads them to immediately identify any changes in their addictive brand by instilling a sense of anxiety, even when the brand makes small changes in its products.

Starting from these previous findings, the purpose of the last hypothesis is to empirically test the possible relationship between brand addiction and brand exclusiveness. Thus, it could be hypothesized that the more the consumers are addicted to a brand, the more they develop brand exclusiveness behaviors. Hence, the seventh hypothesis is structured as follows:

H7. Brand addiction has a positive effect on brand exclusiveness.

Figure 1 depicts the overall model under investigation, with the research hypotheses.

\section{Methodology}

\subsection{Design, participants, measures}

Data were collected from 529 university students using a Webbased self-completion survey. Based on the assumption that young people are more active in the relationships with brands; are exposed to brands from their early life; possess a high level of brand consciousness; are constantly engaged with brands (Jain and Sharma, 2019; Fernandez, 2009), this specific target 
Figure 1 Conceptual model

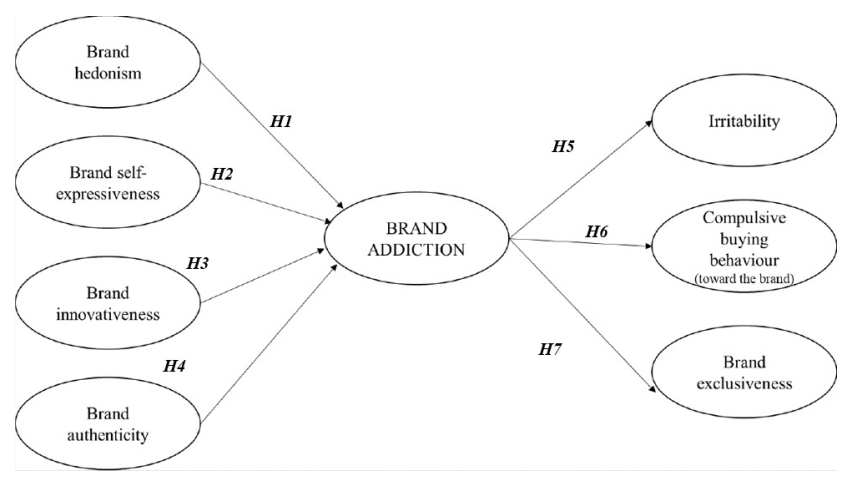

has been chosen for the study. Notably, young people are defined to be under 29 years old[1]. For this reason, university students have been selected, as they are highly representative of the young Italian population. University students are usually considered as people aged between 18 and 25 (Sari et al., 2015). Moreover, in Italy, the average age at graduation is 26 (Eurostat, 2016 [2]). Therefore, university students could be viewed as representative of Italian people under 30 years old, with similar lifestyle features (Savelli et al., 2019). Second, university students have been chosen, as they represent a profitable segment with high-status consumption levels, making them a very remarkable target for marketers and branding professionals (Eastman and Liu, 2012).

The survey was carried out in the Italian language. Through the adoption of a professional platform for surveys (SondaggioOnline), the data collection took place from October 2019 to December 2019.

In the first phase, participants were asked to specify a brand toward which they feel addicted. In total, 624 respondents started the survey, but we did not consider the responses coming from participants who have stated that they are not addicted to any brand $(n=95)$.

With a total of 529 respondents, the sample is above the rule of 200, and the sample to item ratio is 12.7 , which is more than twice as high compared to the acceptable ratio of 5:1 (Gorsuch, 1983). Thus, adequate sample size is achieved.

Overall, the sample is composed of students with age between 18 and 29 years old. A total of $23 \%$ of the respondents were male and $77 \%$ were females.

Concerning the constructs' selection, all of them have been operationalized using scales specifically developed for the brand context.

In particular, for brand addiction, the scale of Mrad and Cui (2017) has been adopted, whereas for the brand hedonism and brand self-expressiveness, the scales of Carroll and Ahuvia (2006) have been selected and subsequently adapted. With respect to brand innovativeness, Pappu and Quester scale (2016) has been adopted, whereas the scale of Schallehn et al. (2014) has been used for brand authenticity. The compulsive buying behavior scale of Edwards (1993) has been adopted for the compulsive buying behavior toward the brand construct. However, in a subsequent phase, this scale has been adapted to the specific objective of the paper, which is not the analysis of the general compulsive buying attitude (investigated by different contributions focused on the brand addiction topic), but the examination of the compulsive buying behavior toward the addicted brand. Finally, the irritability and brand exclusiveness constructs have been measured, starting from the conceptualizations proposed by Cui et al. (2018), which have been then adapted to the present study.

Appendix contains the complete list of the items, Cronbach's alpha for each scale and the source adopted for each construct. All final scales proved to be reliable with Cronbach's alpha values $>0.80$.

\section{Results}

From a descriptive point of view, the survey's results allowed to collect information about the brands nominated by the interviewees (Table 3). Notably, the different brand names have been grouped into specific categories to identify the sectors from which they mainly come. More in detail, a majority of addictive brands belong to four categories, such as clothing/accessories $(n=313)$, telecommunications/technology $(n=85)$, food/beverage $(n=56)$ and beauty/cosmetics $(n=32)$.

In the second phase, structural equation modeling has been employed by using SPSS AMOS to assess the relationships among underlying constructs. The results suggest acceptable model fit with $\chi^{2}=2175.11 ; \mathrm{df}=863 ; p=0.00 ; \chi^{2} / \mathrm{df}=2.52$; $\mathrm{IFI}=0.93, \mathrm{TLI}=0.92$ and $\mathrm{CFI}=0.93 ; \mathrm{RMSEA}=0.05$. brand hedonism does not significantly influence brand addiction $(\beta=$ 0.03 ; $p=0.46$ ), thus $H 1$ is not confirmed. On the contrary, brand self-expressiveness $(\beta=0.49 ; p<0.01)$, brand innovativeness $(\beta=0.21 ; p<0.01)$ and brand authenticity $(\beta=$ $0.10 ; p=0.01$ ) lead to brand addiction, thus confirming $H 2$, $H 3$ and $H 4$.

Further, brand addiction has a strong positive influence on irritability $(\beta=0.53 ; p<0.01)$, compulsive buying behavior toward the brand $(\beta=0.67 ; p<0.01)$ and brand exclusiveness $(\beta=0.54 ; p<$ 0.01 ), thus confirming H5, H6 and H7 (Figure 2).

\section{Discussions}

\subsection{Theoretical implications}

The present study aimed to deepen the brand addiction construct analysis, still little investigated by the existing literature (Cui et al., 2018). In particular, the work has attempted to respond to the need, underlined by previous contributions (Mrad et al., 2020; Mrad, 2018; Mrad and Cui,

Table 3 Addictive brands (subdivided into sectors)

\begin{tabular}{lcr}
\hline Sector & Number & $(\%)$ \\
\hline Clothing/accessories & 313 & 59.2 \\
Telecommunication/technology & 85 & 16.1 \\
Food/beverage & 56 & 10.6 \\
Beauty/cosmetics & 32 & 6.0 \\
Automobiles & 13 & 2.5 \\
Entertainment & 12 & 2.3 \\
Online Platform & 7 & 1.3 \\
Cigarettes & 4 & 0.8 \\
Furniture & 3 & 0.6 \\
Food supplements & 2 & 0.4 \\
Household appliances & 2 & 0.4 \\
Total & 529 & 100.0 \\
\hline
\end{tabular}


Figure 2 Structural model

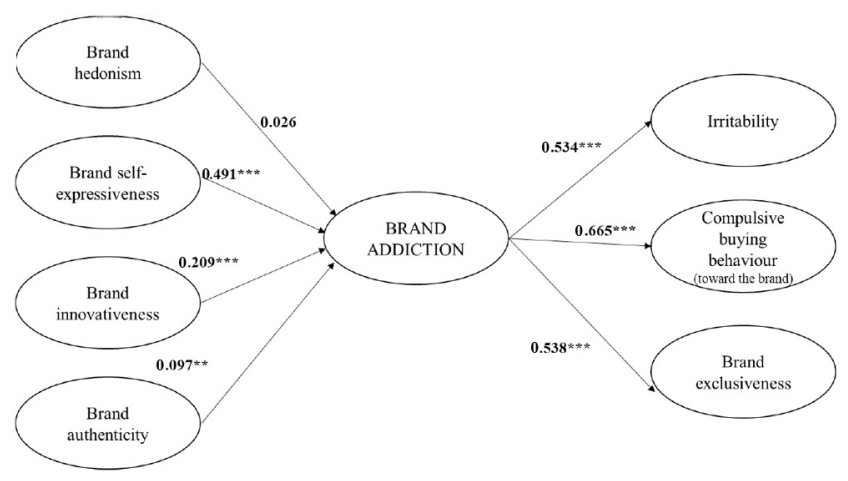

2017), to empirically test possible antecedents and outcomes of brand addiction, thus corroborating or not the qualitative findings from the extant research.

For what concerns the antecedents, the research started from previous contributions (Pappu and Quester, 2016; Schallehn et al., 2014; Bauer et al., 2007; Carroll and Ahuvia, 2006) that investigated the effect of specific brand features (i.e. brand hedonism, brand self-expressiveness, brand innovativeness and brand authenticity) in consumer-brand connections different from brand addiction. Then, the influence of these brand characteristics has been examined within an ever stronger way of brand-consumer engagement because, to the best of the authors' knowledge, no research studies have tested the relationships between these features and brand addiction. In doing so, the paper attempted to contribute to the extant literature because even if some overlaps between brand addiction, brand love and brand loyalty can exist, research demonstrates that brand addiction is a different and newly emerged concept within consumer-brand relations (Cui et al., 2018).

Regarding the consumers' outcomes, the study analyzed three brand addiction consequences (i.e. irritability, compulsive buying behavior toward the brand and brand exclusiveness) identified by previous research (Mrad, 2018; Cui et al., 2018), which have not yet been empirically tested.

Findings highlighted how the brand characteristics of selfexpressiveness, innovativeness and authenticity have a positive influence on the establishment of addictive relationships between brands and customers. In particular, brand selfexpressiveness is the factor with the highest effect on brand addiction, thus revealing that the more the brand is able to express the consumers' inner-self, the more they could become addicted to it.

Conversely, no significant relationship has been found between brand hedonism and brand addiction. This result could be explained in light of the fact that, although previous studies identified a positive relationship between hedonic features of a brand/product and both brand love (Carroll and Ahuvia, 2006) and brand passion (Bauer et al., 2007), when customers become addicted to a brand, this characteristic is put on the back burner, as other elements become more significant, such as brand innovativeness, brand authenticity and brand self-expressiveness.

At once, findings also showed how brand addiction could negatively influence consumers by leading them to feel emotions of irritability and to adopt behaviors of obsessive exclusiveness and compulsive buying toward the brand.

Overall, these results support the detection of negative aspects of brand addiction, as identified in previous studies (Cui et al., 2018; Fournier and Alvarez, 2013). Notably, brand addiction represents an intense consumer-brand relationship nurtured by the brand characteristics of self-expressiveness, innovativeness and authenticity and characterized by potentially negative consequences for brand addicts who may experience feelings of irritability and anxiety by also adopting compulsive and obsessive attitudes. Thereby, the study provides a further brand addiction conceptualization, thus enhancing the few extant contributions (Mrad and Cui, 2020; Cui et al., 2018; Mrad, 2018; Mrad and Cui, 2017) that have tried in their turn to define it.

\subsection{Managerial implications}

At the managerial level, the paper identified possible strategies that firms addressing toward young consumers could adopt to strengthen the possibilities of transforming them into addicted ones and avoid/reduce the negative consequences of brand addiction.

Notably, the study detected two specific spheres related to the brand addiction construct: one connected to the brand's characteristics and the other to the consumers' emotionalbehavioral outcomes.

Indeed, the analysis of the brand addiction antecedents has made it possible to underline some specific features on which marketers should particularly focus their attention to encourage the formation of devotional relationships with their younger consumers.

Marketers should, especially:

- emphasize the characteristics of innovation and personalization/customization of their brands through constant research aimed at periodically introducing novelties and highly customized products; and

- guarantee an authentic offer system perfectly in line with the firm's mission and vision.

In doing so, firms will satisfy customers' needs of innovativeness, self-expressiveness and authenticity, thus increasing the possibility that they become highly devoted customers.

Within this context, the $\mathrm{R} \& \mathrm{D}$ and communication offices become key departments whose primary task will be to search for continuous innovations and establish constant and interactive relationships with their customers. In particular, creating online platforms for brand-consumer interaction or the adoption of the new social media tools (e.g. Instagram stories polls) can help marketers promote their customers' selfexpression.

On the other hand, the analysis of the brand addiction outcomes enabled identifying two sub-spheres: a psychological and a behavioral one.

Behaviorally, the identified customers' obsessive and compulsive attitudes are not, per se, actions that acquire negative connotations for firms since they favor, on the contrary, sales and the formation of devotional consumersbrands relationships. 
Conversely, from the psychological perspective, brand addiction leads customers to experience feelings of irritability, anxiety and frustration, which could potentially get them away from the brand, especially if customers feel like their favorite brand has wronged them (e.g. unexpected deletion of a specific brand's product, abrupt changes of specific products/models of the brand).

Overall, these emotional states must be constantly monitored by the firm, both in terms of marketing activities and from a strategic point of view.

In the first case, it will be necessary to do the following:

- constantly monitor the brand's offer (e.g. ensuring that products/models highly requested by customers are always available at physical stores/online channels);

- guarantee an adequate range of offers over time; and

- develop highly interactive and personalized communications with the customers by also adopting the new Web technologies (e.g. social media, live chats, forums, blogs).

In this way, brand addicts can receive more quick and satisfactory responses and recoveries from firms (Bijmolt et al., 2014), thus mitigating their anxiety and irritability deriving from any possible changes in their favorite brand.

Finally, at a strategic level, firms will have to focus on consumer profiling through careful segmentation and targeting analysis. In this way, the characteristics of the devoted consumers can be meticulously identified, thus planning the marketing activities to be developed in the medium to longterm, on the one hand, and avoiding, on the other, to run into customers' states of dissatisfaction, which could transform them from ideal customers to fearsome haters for the firm.

At the same time, the customers' obsessive and compulsive behaviors emerged from the study underline how brand addiction could also assume dark features for brand addicts.

Consequently, even if these behaviors do not assume, per se, negative connotations for firms, they can acquire negative implications for consumers. For this reason, the role of firms and marketers is related to not only the creation of short-term profits but also the offer of healthy options, thus enhancing the standard of living of their consumers and helping the entire society (Mrad and Cui, 2020). Moreover, firms should adopt strategies specifically aimed at avoiding ethical complications. Notably, brand addiction brings with it controversial issues related to the fact that it could be highly debatable to encourage consumers to create addicted relationships with brands. Indeed, these relations could carry with them very negative consequences. With this in mind, firms can exploit the online channels not only to monitor their customers' emotional states - as mentioned above - but also to promote positive and ethically correct messages against extremely compulsive buying behaviors and negative mood states. Therefore, it becomes crucial to underline that addiction to a brand should not result in overspending, anxiety and irritability, but, on the contrary, it should bring with it only positive states of mind. At the same time, marketers can also adopt additional tools (e.g. television advertising, sales campaigns, point-of-sale advertising) to spread the same messages even in the offline context.

More specifically, firms should create social messages and advertising campaigns highlighting, on the one hand, the possibility - for customers - to build positive and exclusive relationships with their brands, and on the other, the risk to run into negative consumption behaviors if their relationships become insane.

Overall, all these actions could reduce the dark connotations of brand addiction, emerged from this study, as literature highlighted that increasing the guilt conscience will enhance consumers' ethical intents (Steenhaut and Van Kenhove, 2006). Finally, by promoting these types of messages, marketers can defend themselves from ethical complaints, which represent today one of the most destructive criticisms for firms and brands (Lopes et al., 2020).

\subsection{Limitations and future research directions}

The analysis of the brand addiction construct represents an emerging field with several issues that still need to be addressed (Mrad et al., 2020; Cui et al., 2018). The present study attempted to provide a response to the call for more research into this topic.

However, the main limitations are related to the adopted sample. In particular, emotions toward brands such as love and hate (and consequently also addiction) represent social and cultural constructs (Hegner et al., 2017). Given that our sample is composed of university students attending an Italian University, it will be interesting to analyze if our proposed conceptual model could be applied in other geographical contexts and target groups, thus permitting to identify possible similarities/differences in brand addiction motivations and behaviors. Moreover, considering that results underlined that brand hedonism is not a significant predictor of brand addiction, it could be interesting, in future research studies, to analyze when and why consumers can become addicted to hedonic brands.

Furthermore, future research might:

- focus on the effects of consumers' characteristics (e.g. age, sex and employment situation) and personality traits (e.g. big five personality traits) on their brand addiction behaviors;

- analyze additional factors leading customers to become addicted to a brand; and

- include in the model, possible mediators - or moderators such as the product category (e.g. clothing, high-tech brands), involvement with the product and selfenhancement.

\section{Notes}

1 Eurostat, https://ec.europa.eu/eurostat/web/youth

2 http://ec.europa.eu/eurostat/statistics-explained/index. php/Population_and_social_conditions

\section{References}

Aaker, D.A. (2009), Managing Brand Equity, Simon and Schuster, New York, NY.

Albert, N. and Merunka, D. (2013), "The role of brand love in consumer-brand relationships", fournal of Consumer Marketing, Vol. 30 No. 3, pp. 258-266. 
Barone, M.J. and Jewell, R.D. (2013), “The innovator's license: a latitude to deviate from category norms", fournal of Marketing, Vol. 77 No. 1, pp. 120-134.

Barone, M.J. and Jewell, R.D. (2014), "How brand innovativeness creates advertising flexibility", fournal of the Academy of Marketing Science, Vol. 42 No. 3, pp. 309-321.

Bauer, H.H., Heinrich, D. and Martin, I. (2007), "How to create high emotional consumer-brand relationships? The causalities of brand passion", Proceedings of the Australian and New Zealand Market Acad, University of Otago, pp. 2189-2198.

Bijmolt, T., Kre Huizingh, E. and Krawczyk, A. (2014), "Effects of complaint behaviour and service recovery satisfaction on consumer intentions to repurchase on the internet", Internet Research, Vol. 24 No. 5, pp. 608-628.

Boisvert, J. and Ashill, N.J. (2011), "How brand innovativeness and quality impact attitude toward new service line extensions: the moderating role of consumer involvement", Fournal of Services Marketing, Vol. 25 No. 7, pp. 517-527.

Born, L. and Steiner, M. (1999), "Irritability: the forgotten dimension of female-specific mood disorders", Archives of Women's Mental Health, Vol. 2 No. 4, pp. 153-167.

Burnett, J. and Hutton, R.B. (2007), "New consumers need new brands", Fournal of Product \& brand Management, Vol. 16 No. 5, pp. 342-347.

Carroll, B.A. and Ahuvia, A.C. (2006), "Some antecedents and outcomes of brand love", Marketing Letters, Vol. 17 No. 2, pp. 79-89.

Cui, C.C., Mrad, M. and Hogg, M.K. (2018), "brand addiction: exploring the concept and its definition through an experiential lens", fournal of Business Research, Vol. 87, pp. 118-127.

Dickstein, D.P. and Leibenluft, E. (2012), "Beyond dogma: from diagnostic controversies to data about pediatric bipolar disorder and children with chronic irritability and mood dysregulation", The Israel fournal of Psychiatry and Related Sciences, Vol. 49 No. 1, pp. 52-61.

Eastman, J.K. and Liu, J. (2012), “The impact of generational cohorts on status consumption: an exploratory look at generational cohort and demographics on status consumption", fournal of Consumer Marketing, Vol. 29 No. 2, pp. 93-102.

Edwards, E.A. (1993), "Development of a new scale for measuring compulsive buying behavior", Financial Counseling and Planning, Vol. 4 No. 1, pp. 67-84.

Eggers, F., O'Dwyer, M., Kraus, S., Vallaster, C. and Güldenberg, S. (2013), "The impact of brand authenticity on brand trust and SME growth: a CEO perspective", Fournal of World Business, Vol. 48 No. 3, pp. 340-348.

Eisingerich, A.B. and Rubera, G. (2010), "Drivers of brand commitment: a cross-national investigation", fournal of International Marketing, Vol. 18 No. 2, pp. 64-79.

Eurostat (2016), “Culture statistics (2016 edition), Collection: Statistical books", ISBN: 978-92-79-52215-4, available at: https://ec.europa.eu/eurostat/documents/3217494/7551543/ KS-04-15-737-EN-N.pdf/648072f3-63c4-47d8-905a6fdc742b8605 (accessed 10 August 2020).

Fernandez, P.R. (2009), "Impact of branding on gen Y's choice of clothing", Fournal of the South East Asia Research
Centre for Communications and Humanities, Vol. 1 No. 1, pp. 79-95.

Fournier, S. (1998), "Consumers and their brands: developing relationship theory in consumer research", Fournal of Consumer Research, Vol. 24 No. 4, pp. 343-353.

Fournier, S. and Alvarez, C. (2013), "Relating badly to brands", fournal of Consumer Psychology, Vol. 23 No. 2, pp. 253-264.

Gorsuch, R.L. (1983), Factor Analysis, Erlbaum, Hillsdale, NJ.

Hegner, S.M., Fetscherin, M. and Van Delzen, M. (2017), "Determinants and outcomes of brand hate", fournal of Product E brand Management, Vol. 26 No. 1, pp. 13-25.

Jain, K. and Sharma, I. (2019), "Negative outcomes of positive brand relationships", fournal of Consumer Marketing, Vol. 36 No. 7, pp. 986-1002.

Karjaluoto, H., Munnukka, J. and Kiuru, K. (2016), "brand love and positive word of mouth: the moderating effects of experience and price", fournal of Product \& brand Management, Vol. 25 No. 6, pp. 527-537.

Kuikka, A. and Laukkanen, T. (2012), "brand loyalty and the role of hedonic value", fournal of Product E brand Management, Vol. 21 No. 7, pp. 529-537.

Lee, S.H. and Workman, J.E. (2015), "Determinants of brand loyalty: self-construal, self-expressive brands, and brand attachment", International fournal of Fashion Design, Technology and Education, Vol. 8 No. 1, pp. 12-20.

Lopes, E.L., Yunes, L.Z., de Lamônica Freire, O.B., Herrero, E. and Pinochet, L.H.C. (2020), "The role of ethical problems related to a brand in the purchasing decision process: an analysis of the moderating effect of complexity of purchase and mediation of perceived social risk", Fournal of Retailing and Consumer Services, Vol. 53, p. 101970.

Loureiro, S.M.C., Ruediger, K.H. and Demetris, V. (2012), "brand emotional connection and loyalty", fournal of brand Management, Vol. 20 No. 1, pp. 13-27.

Martin, I.M., Kamins, M.A., Pirouz, D.M., Davis, S.W., Haws, K.L., Mirabito, A.M. and Grover, A. (2013), "On the road to addiction: the facilitative and preventive roles of marketing cues", Fournal of Business Research, Vol. 66 No. 8, pp. 1219-1226.

Mrad, M. (2018), "brand addiction conceptual development", Qualitative Market Research: An International fournal, Vol. 21 No. 1, pp. 18-38.

Mrad, M. and Cui, C.C. (2017), "brand addiction: conceptualization and scale development", European fournal of Marketing, Vol. 51 Nos 11/12, pp. 1938-1960.

Mrad, M. and Cui, C.C. (2020), "Comorbidity of compulsive buying and brand addiction: an examination of two types of addictive consumption", Fournal of Business Research, Vol. 113, available online 29 October 2019.

Mrad, M., Majdalani, J., Cui, C.C. and El Khansa, Z. (2020), "brand addiction in the contexts of luxury and fast-fashion brands", Fournal of Retailing and Consumer Services, Vol. 55, p. 102089.

Pappu, R. and Quester, P.G. (2016), "How does brand innovativeness affect brand loyalty?", European fournal of Marketing, Vol. 50 Nos 1/2, pp. 2-28. 
Park, H.J. and Burns, L.D. (2005), "Fashion orientation, credit card use, and compulsive buying", fournal of Consumer Marketing, Vol. 22 No. 3, pp. 135-141.

Quellet, J.F. (2006), "The mixed effects of brand innovativeness and consumer innovativeness on attitude towards the brand", paper presented at the ASAC Conference, Banff, Alberta, available at: https:/it.scribd. com/document/44715162/The-Mixed-Effects-Of (accessed 18 December 2019).

Reimann, M., Castaño, R., Zaichkowsky, J. and Bechara, A. (2012), "How we relate to brands: psychological and neurophysiological insights into consumer-brand relationships", Fournal of Consumer Psychology, Vol. 22 No. 1, pp. 128-142.

Ruane, L. and Wallance, E. (2015), "brand tribalism and selfexpressive brands: social influences and brand outcomes", Fournal of Product \& brand Management, Vol. 24 No. 4, pp. 333-348.

Sari, A.A., Kusuma, H.E. and Tedjo, B. (2015), "A strategic planning for a college student-segment shopping mall", International Research fournal of Business Studies, Vol. 4 No. 2, pp. 157-169.

Sarkar, A. and Sreejesh, S. (2014), "Examination of the roles played by brand love and jealousy in shaping customer engagement", Fournal of Product \& brand Management, Vol. 23 No. 1, pp. 24-32.

Savelli, E., Bravi, L., Murmura, F. and Pencarelli, T. (2019), "Understanding the consumption of traditional-local foods through the experience perspective: the case of the truffle", British Food fournal, Vol. 121 No. 6, pp. 1261-1280.

Schallehn, M., Burmann, C. and Riley, N. (2014), "brand authenticity: model development and empirical testing", fournal of Product E brand Management, Vol. 23 No. 3, pp. 192-199.
Shams, R., Alpert, F. and Brown, M. (2015), "Consumer perceived brand innovativeness: conceptualization and operationalization", European fournal of Marketing, Vol. 49 Nos 9/10, pp. 1589-1615.

Shams, R., Brown, M. and Alpert, F. (2017), "The role of brand credibility in the relationship between brand innovativeness and purchase intention", fournal of Customer Behaviour, Vol. 16 No. 2, pp. 145-159.

Shoham, A. and Makovec Brenčič, M. (2003), "Compulsive buying behavior", fournal of Consumer Marketing, Vol. 20 No. 2, pp. 127-138.

Srivastava, N., Dash, S.B. and Mookerjee, A. (2016), "Determinants of brand trust in high inherent risk products: the moderating role of education and working status", Marketing Intelligence \& Planning, Vol. 34 No. 3, pp. 394-420.

Steenhaut, S. and Van Kenhove, P. (2006), "The mediating role of anticipated guilt in consumers' ethical decisionmaking", fournal of Business Ethics, Vol. 69 No. 3, pp. 269-288.

Sussman, S. and Sussman, A.N. (2011), "Considering the definition of addiction", International fournal of Environmental Research and Public Health, Vol. 8 No. 10, pp. 4025-4038.

Swimberghe, K.R., Astakhova, M. and Wooldridge, B.R. (2014), "A new dualistic approach to brand passion: harmonious and obsessive", fournal of Business Research, Vol. 67 No. 12, pp. 2657-2665.

Thomson, M., MacInnis, D.J. and Park, C.W. (2005), "The ties that bind: measuring the strength of consumers' emotional attachments to brands", fournal of Consumer Psychology, Vol. 15 No. 1, pp. 77-91. 


\section{Appendix}

Table A1 Construct operationalization

\begin{tabular}{|c|c|c|c|c|}
\hline Constructs & Ite & & Cronbach $\alpha$ & Sources \\
\hline $\begin{array}{l}\text { Brand } \\
\text { addiction }\end{array}$ & $\begin{array}{l}1 \\
2 \\
3 \\
4\end{array}$ & $\begin{array}{l}\text { I try very hard to get everything from my favorite brand; } \\
\text { I often fail to control myself from purchasing products of my favorite } \\
\text { brand; } \\
\text { I often find myself thinking about my favorite brand; } \\
\text { I tend to give up some life activities and duties such as the } \\
\text { occupational, academic and familial in order to fulfil some activities } \\
\text { related to my favorite brand; } \\
\text { I tend to allocate certain portion of my monthly income to buy the } \\
\text { products of my favorite brand; } \\
\text { I usually remember tenderly the previous experience with my favorite } \\
\text { brand; } \\
\text { I experience a state of impatience immediately before I can get hold } \\
\text { of the products of my favorite brand; } \\
\text { I follow my favorite brand's news all the time; } \\
\text { I usually plan when the next purchase of my favorite brand will be }\end{array}$ & 0.835 & $\begin{array}{l}\text { Mrad and Cui } \\
(2017)\end{array}$ \\
\hline $\begin{array}{l}\text { Brand } \\
\text { hedonism }\end{array}$ & $\begin{array}{l}1 \\
2 \\
3 \\
4 \\
5\end{array}$ & $\begin{array}{l}\text { This particular brand is functional/Is pleasurable; } \\
\text { This particular brand affords enjoyment/performs a task; } \\
\text { This particular brand is useful/fun; } \\
\text { This particular brand is a sensory experience/does a job; } \\
\text { This particular brand is a necessity/an indulgence }\end{array}$ & 0.800 & $\begin{array}{l}\text { Carroll and } \\
\text { Ahuvia (2006) }\end{array}$ \\
\hline $\begin{array}{l}\text { Brand self- } \\
\text { expressiveness }\end{array}$ & $\begin{array}{l}1 \\
2 \\
3 \\
4 \\
5 \\
6 \\
7 \\
8\end{array}$ & $\begin{array}{l}\text { This brand symbolizes the kind of person I really am inside; } \\
\text { This brand reflects my personality; } \\
\text { This brand is an extension of my inner self; } \\
\text { This brand mirrors the real me; } \\
\text { This brand contributes to my image; } \\
\text { This brand adds to a social 'role' I play; } \\
\text { This brand has a positive impact on what others think of me; } \\
\text { This brand improves the way society views me }\end{array}$ & 0.897 & $\begin{array}{l}\text { Carroll and } \\
\text { Ahuvia (2006) }\end{array}$ \\
\hline $\begin{array}{l}\text { Brand } \\
\text { innovativeness }\end{array}$ & $\begin{array}{l}1 \\
2 \\
3 \\
4\end{array}$ & $\begin{array}{l}\text { The brand introduces innovative products totally new to the market; } \\
\text { The brand uses new technology; } \\
\text { The brand introduces new products first into the market; } \\
\text { The brand introduces products that cause significant changes in the } \\
\text { market place }\end{array}$ & 0.870 & $\begin{array}{l}\text { Pappu and } \\
\text { Quester (2016) }\end{array}$ \\
\hline $\begin{array}{l}\text { Brand } \\
\text { authenticity }\end{array}$ & $\begin{array}{l}1 \\
2 \\
3 \\
4 \\
5 \\
6 \\
7 \\
8 \\
8\end{array}$ & $\begin{array}{l}\text { The brand fulfils its promise consistently; } \\
\text { The current brand behavior fits to its brand promise; } \\
\text { The brand promise and its present actions are in line with each other; } \\
\text { In the past, the brand has already fulfilled its brand promise; } \\
\text { The previous behavior of the brand fits to its current brand promise; } \\
\text { The brand promise and its past actions are in line with each other; } \\
\text { The way how the brand fulfils its brand promise is very different from } \\
\text { competing brands; } \\
\text { The way how the brand fulfils its brand promise is unique; } \\
\text { The brand fulfils its brand promise in a distinct way }\end{array}$ & 0.900 & $\begin{array}{l}\text { Schallehn et al. } \\
\text { (2014) }\end{array}$ \\
\hline
\end{tabular}


Table A1

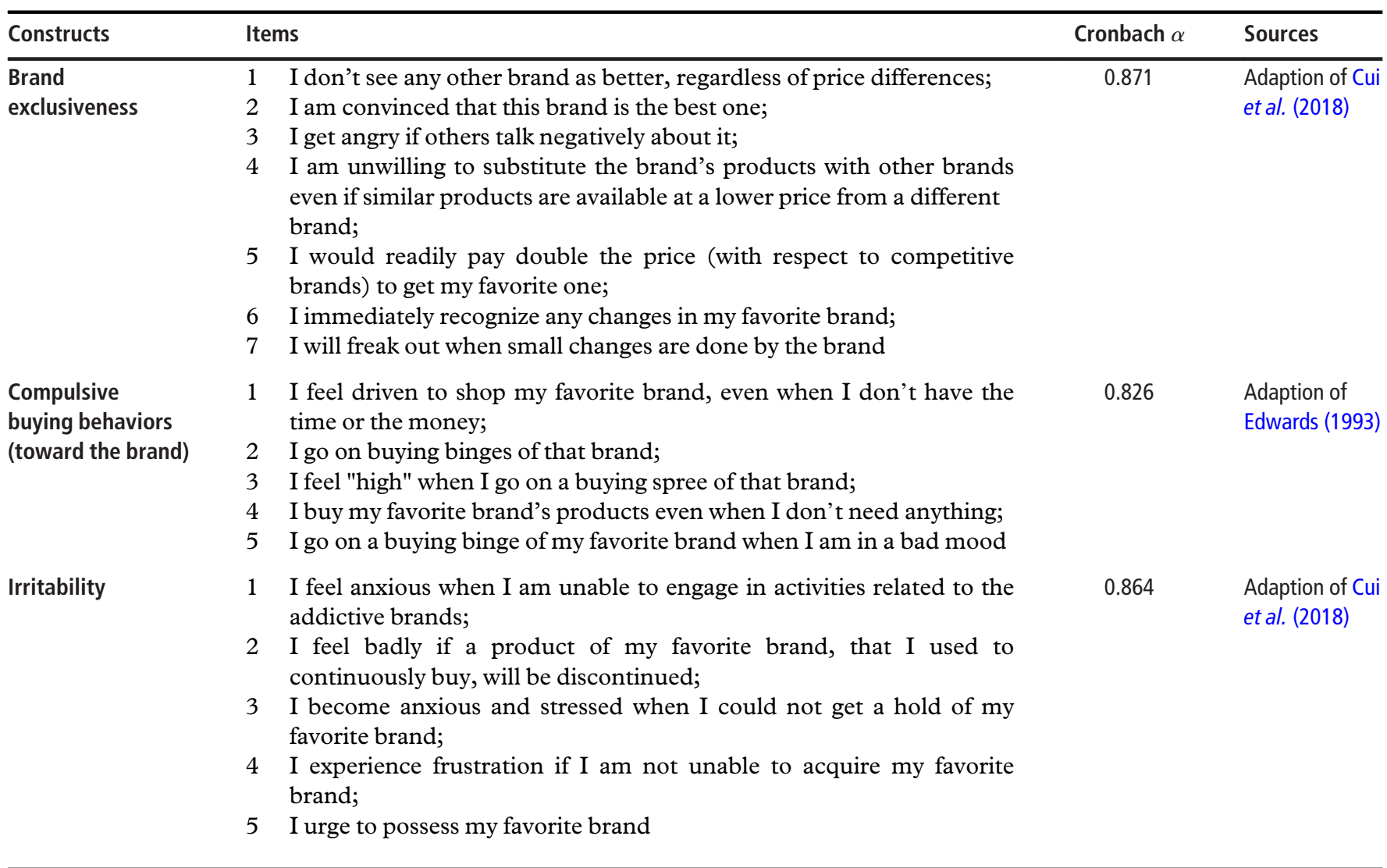

\section{About the authors}

Barbara Francioni is Assistant Professor in Business Economics and Management in the Department of Communication Sciences, Humanities and International Studies, University of Urbino. Her research interests focus on the internationalization of SMEs, international marketing and marketing. Her work has appeared in numerous journals, including International Business Review, Management Decision, Fournal of Strategic Marketing, Fournal of Small Business and Enterprise Development, Fournal of East-West Business and others. Barbara Francioni is the corresponding author and can be contacted at: barbara.francioni@uniurb.it

Ilaria Curina is Research Fellow in Economics and Management at the Department of Communication Sciences, Humanities and International Studies, University of Urbino. Her research interests focus on the exhibition sector trends (which characterized the main issue of her doctoral dissertation), the adoption and management of Social Media and Information and Communication technologies and the analysis and elaboration of a possible index for the measurement of firms' online presence (applied to different sectors of analysis).

Sabrina M. Hegner is Professor in the Faculty of Business and Economics at the University of Bremen (Germany). Before this teaching position, she taught Business Psychology as Professor at the Bielefeld University of Applied Sciences. She holds PhD from the University of Bremen in Germany. Her primary research interests include the creation of brand relationships, crisis communication, innovation and technology acceptance and socially responsible behaviors.

Marco Cioppi is Associate Professor in Business Economics and Management at the Department of Communication Sciences, Humanities and International Studies at the University of Urbino. His main research interests concern strategy and organization of SME'S and the management of Information and Communication Technologies. $\mathrm{He}$ is teaching courses on Business Economics and Management and Internet Marketing at both the School of Economics and School of Foreign Languages in the same university. 